\title{
IMPLIKASI YURIDIS DARI KENTENTUAN DIVERSI DALAM INSTRUMEN INTERNASIONAL ANAK DALAM HUKUM ANAK DI INDONESIA
}

\author{
Nurini Aprilianda \\ Fakultas Hukum Universitas Brawijaya Malang \\ (nurini.aprilianda@ub.ac.id)
}

\begin{abstract}
Legal process on disputes settlement which involved children in Indonesia is distressed, as it put children in detention since on investigation process until on trial process. Putting children in detention should be taken as a final effort as well as in a short period of time as it stated clearly on article 37 CRC. After living from detention, children suffer from stigmatisation which given by the society. So that, alternative disputes settlement which involve children can be done by diversion. In fact, diversion has not been regulated in Indonesian law.
\end{abstract}

Keyword : diversion, juvenile delinquent, legal protection

\begin{abstract}
ABSTRAK:
Proses formal dalam penyelesaian perkara anak yang berlangsung hingga saat ini berawal dari penyidikan hingga persidangan cukup memprihatinkan, karena anak ditahan mulai dari tingkat penyidikan dan berakhir dengan penjatuhan pidana penjara oleh hakim. Penahanan dan penjatuhan pidana penjara terhadap anak seharusnya sebagai upaya terakhir dan untuk jangka waktu pendek sebagaimana diamanatkan dalam Pasal 37 Konvensi Hak-Hak Anak. Secara psikologis, kondisi itu dapat mengganggu anak dan setelah keluar dari penjara, mereka pun tertekan karena stigma yang diberikan oleh masyarakat. Salah satu bentuk alternatif penyelesaian perkara anak dapat dilakukan melalui diversi/pengalihan perkara di luar jalur formal. Namun diversi belum diatur dalam peraturan perudang-undangan di Indonesia.
\end{abstract}

Kata Kunci : diversi, anak nakal, perlindungan hukum

\section{Latar Belakang}

Setiap tahun ada sekitar 4.000 anak yang dibawa ke pengadilan dan berakhir pada hilangnya kebebasan, yaitu penjara. Di dalam penjara, mereka dicampur dengan orang dewasa. Secara psikologis, kondisi itu dapat mengganggu anak dan setelah keluar dari penjara, mereka pun tertekan karena stigma yang diberikan oleh masyarakat. ${ }^{1}$ Selain itu, penelitian yang lain juga menggambarkan fakta bahwa di Wilayah Hukum Kota Malang dan Surabaya, tidak terdapat khusus sarana untuk pemisahan tahanan anak, pembuatan ruang sidang anak. Selain itu ditemukan pula fakta bahwa bahwa di PN Surabaya, dari seluruh Anak Nakal mulai tahun 2003-2007 (330 anak), hanya 3 anak yang dijatuhi pidana pengawasan oleh hakim anak sebagaimana diatur dalam Pasal 30 Undang-Undang No.3 Tahun 1997 tentang Pengadilan Anak (UU Pengadilan Anak). Sedangkan PN Malang belum pernah menjatuhkan sanksi berupa tindakan bagi terdakwa anak, padahal UU Pengadilan Anak memberikan alternatif terhadap penjatuhan sanksi bagi terdakwa anak atau Anak Nakal yang tidak hanya pidana penjara tetapi juga sanksi berupa tindakan. Hakim Anak di Pengadilan Negeri Malang tidak pernah menjatuhkan

1 http://64.203.71.11/kompas-cetak/0404/21/Jabar/983566.htm, diakses tanggal 18 Juni 2008. 
sanksi yang lebih ringan dibanding pidana penjara termasuk berupa tindakan kepada terdakwa anak. ${ }^{2}$

Penjatuhan sanksi pidana berupa pidana penjara terhadap anak seharusnya memperhatikan ketentuan bahwa pemidanaan seorang anak harus sesuai dengan hukum sekaligus sebagai upaya terakhir dan hanya untuk jangka waktu pendek sebagaimana diamanatkan dalam Pasal 37 Konvensi Hak-Hak Anak. Dalam Pasal 37 ayat b Konvensi Hak-Hak Anak yang berbunyi: "Tidak seorang anakpun akan dirampas kemerdekaannya secara tidak sah dan sewenang-wenang. Penangkapan, penahanan ataupun pemidanaan seorang anak harus sesuai dengan hukum dan akan diterapkan sebagai upaya terakhir dan untuk jangka waktu yang paling pendek". ${ }^{3}$ Kemudian dalam Pasal 37 ayat c Konvensi Hak-Hak Anak dinyatakan, "Setiap anak yang dirampas kemerdekaannya akan diperlakukan secara manusiawi dan dihormati martabat kemanusiaanya dan dengan memperhatikan kebutuhan-kebutuhan orang seusianya”. ${ }^{4}$

Penjatuhan sanksi terhadap Anak Nakal harus mencerminkan salah satu prinsip dalam Konvensi Hak-Hak Anak yaitu prinsip the best interest of the child (kepentingan yang terbaik bagi anak). Prinsip ini tergambar pada Pasal 3 ayat 1 Konvensi Hak-Hak Anak. Dampak negatif dari proses peradilan anak antara lain: prisonisasi, dehumanisasi dan stigmatisasi yang dikhawatirkan mengganggu perkembangan jiwa anak. Karena itu upaya pengalihan atau diversi sangat penting untuk dilakukan. Diversi dapat mendorong seseorang untuk menjalani suatu program atau kegiatan untuk menghindari penuntutan yang berdampak stigma dan labeling. Hal ini sejalan dengan pendapat Siegel berikut ini.

One of the most important alternatives chosen at intake is nonjudicial disposition or, as it is variously called, nonjudicial adjustment, or (most commonly) diversion. Juvenile diversion is the process of placing youth suspected of law-violating behaviour into treatment-oriented program prior to formal trial and disposition to minimize their penetration into the justice system and thereby avoid stigma and lebeling. Diversion implies more than simply screening involves abandoning effort to apply coercive measures to a defendant. In contrast, diversion encourages and to participate in some specific program or activity to avoid further prosecution". ${ }^{5}$

Pengalihan proses peradilan anak atau diversi berguna untuk menghindari pengaruh negatif dari proses-proses peradilan serlanjutnya dalam administrasi peradilan anak, misalnya labelisasi akibat pernyataan bersalah maupun penjatuhan pidana. Sasaran konsep diversi ini adalah berkurangnya jumlah anak yang ditangkap, ditahan dan dipenjara, menghapuskan stigma/ cap dan mengembalikan anak menjadi manusia normal yang menyadari kesalahannya dan tidak mengulangi perbuatannya sehingga dapat berguna di kemudian hari. ${ }^{6}$

Berdasarkan uraian di atas, menarik untuk diketahui tentang pengaturan diversi dalam instrumen internasional anak dan implikasi yuridis pengaturan diversi dalam instrumen internasional anak bagi perlindungan hukum terhadap anak nakal di Indonesia.

\section{Pembahasan}

Anak Nakal dan Urgensi Diversi

Menurut Pasal 1 butir (1) Undang-Undang Nomor 3 tahun 1997 tentang Pengadilan Anak, pengertian anak adalah orang yang dalam perkara Anak Nakal telah mencapai umur 8 (delapan) tahun tetapi belum mencapai umur 18 (delapan belas) tahun dan belum pernah kawin. Sedangkan pengertian Anak Nakal diatur dalam Pasal 1 butir (2) Undang-Undang Pengadilan Anak, yaitu adalah :

Anak yang melakukan tindak pidana; atau

Anak yang melakukan perbuatan yang dinyatakan terlarang bagi anak, baik menurut peraturan perundang-undangan maupun menurut peraturan hukum lain yang hidup dan berlaku dalam masyarakat yang besangkutan.

2 Made Sadhi Astuti, Dkk, 2007, Perlindungan Hukum Bagi Anak Nakal Pada Proses Persidangan (Studi Di Pengadilan Negeri Malang Dan Pengadilan Negeri Surabaya), Hasil Penelitian Dasar, Universitas Brawijaya Malang.

3 Dikutip dari Konvensi Hak-Hak Anak, diakses dari http://www.unicef.org/voy/media/CRC_bahasa_indonesia_version.pdf

4 Dikutip dari Konvensi Hak-Hak Anak, diakses dari http://www.unicef.org/voy/media/CRC_bahasa_indonesia_version.pdf

5 Larry J. Siegel , Juvenile Delinquency, Wadswort, United State of America, 1986, h. 322.

6 Marlina, Diversi dan Restorative Justice sebagai Alternatif Perlindungan terhadap Anak yang Berhadapan dengan Hukum, Pusat Kajian dan Perlindungan anak (PKPA), Medan, 2007, h.51. 
Namun demikian, berdasarkan Berkas Perkara Mahkamah Konstitusi Nomor. 1/PUU-VIII/2010, Pasal 1 angka 1 UU pengadilan Anak telah diuji secara materiil oleh Mahkamah Konstitusi dan mengalami perubahan. Berdasarkan Putusan Mahkamah Konstitusi ditegaskan, bahwa batas bawah usia anak yang dapat dimintai pertanggungjawaban pidana adalah 12 tahun. Dalam pertimbangannya, MK menyatakan perlu menetapkan batas umur bagi anak untuk melindungi hak konstitusional anak terutama hak untuk tumbuh dan berkembang. Penetapan usia 12 tahun sebagai ambang batas usia bagi anak telah diterima dalam praktik di berbagai Negara. Usia 12 tahun secara relative telah memiliki kecerdasan emosional, mental, dan intelektual yang stabil sesuai psikologi anak dan budaya Indonesia. ${ }^{7}$ Dengan demikian pengertian anak adalah orang yang dalam perkara Anak Nakal telah mencapai umur 12 (dua belas) tahun tetapi belum mencapai umur 18 (delapan belas) tahun dan belum pernah kawin.

Selanjutnya, menurut Siegel, “Juvenile diversion is the process of placing youths suspected of law-violating behavior into treatment-oriented programs prior to informal trial and disposition to minimize their penetration into the justice system and thereby avoid stigma and labeling". ${ }^{8}$ Dengan demikian Pengertian juvenile diversion sendiri adalah suatu proses penempatan tersangka anak dalam suatu treatment program di luar proses peradilan secara formal untuk menghindarkan atau meminimalisasi keterlibatan anak dari peradilan anak utamanya untuk menghindarkan anak dari stigma dan labeling.

Sejalan dengan hal tersebut, Menurut Jack E. Bynum, "Diversion is an attempt to divert, or channel out, youthful offender from the juvenile system". Diversi adalah perbuatan untuk mengalihkan atau menempatkan pelaku anak keluar dari sistem peradilan anak. ${ }^{9}$ Menurut Paulus, diversi sangat penting untuk diperhatikan dalam penanganan anak pelaku delinkuen, karena dapat menghindarkan anak dari proses stigmatisasi yang lazimnya terjadi dalam proses pemidanaan anak melalui sistem peradilan anak. Dari sisi perlin- diversi sangat diperlukan, karena melalui diversi, kemungkinan penuntutan pidana gugur, rekam jejak kriminal anak menjadi tidak ada dan dengan sendirinya stigmatisasi anak juga tidak terjadi. ${ }^{10}$

Berdasarkan uraian di atas yang dimaksud dengan diversi dalam penelitian ini adalah proses penyelesaian perkara anak nakal di luar jalur formal yang dilakukan oleh pejabat yang berwenang, baik polisi, jaksa maupun hakim, dengan tujuan menghindarkan keterlibatan anak dalam sistem peradilan anak dan menghindarkan anak dari stigma.

Eksistensi Diversi dalam Instrumen Internasional Anak

Melalui sejumlah instrumen hukum, masyarakat internasional telah mengetahui kedudukan khusus anak nakal. Untuk menjaga tujuan menghindarkan anak dari sistem peradilan pidana dan menyerahkannya kembali pada masyarakat, maka diatur tentang hal-hal khusus untuk mencegah tindakan kesewenang-wenangan pada anak nakal dalam administrasi peradilan. ${ }^{11}$ Administrasi peradilan anak merupakan seperangkat ketentuan yang bertujuan memberikan perlindungan hukum terhadap anak. Instrumen internasional berikut ini mengatur administrasi peradilan :

Konvensi Hal Anak (Convention on The Rights of The Child);

Pedoman PBB untuk pencegahan Pelanggaran Hukum Anak (United Nations Guidelines for the Prevention of Juvenile Delinquency/ Riyadh Guidelines);

Peraturan Standar Minimum PBB untuk Admisnistrasi Peradilan Anak/ Standard Minimum Rules for the Administration of Juvenile Justice (SMR-JJ atau sering disebut The Beijing Rules);

Peraturan PBB bagi Perlindungan Anak yang Dicabut Kebebasan mereka (United Nations Rules for the Protection of Juveniles Deprived of Their Liberty/UNRPJ);

Peraturan Standar Minimum bagi Tindakan non Penahanan (United Nations Standard Minimum Rules for Non-Custodial Measures/ Tokyo Rules). ${ }^{12}$

\footnotetext{
7 Batas Usia Anak dapat Dipidana, diakses dari http://m.hukumonline.com/berita/baca/lt4d669dccee142/batas-usia-anak-dapat-dipidananaik tanggal 25 Februari 2011.

8 Larry J Siegel, Op.cit.

9 Marlina, Op.cit, h. 83.

10 Paulus Hadisuprapto, Delinkuensi Anak Pemahaman dan Penanggulangannya, Bayumedia, Malang, 2008, h. 208-209.

11 C. De Rover. To Serve and To Protect Acuan Universal Penegakan HAM. Raja Grafindo Persada, Jakarta, 2000, Hal. $372-373$.

12 Ibid. Hal 371-373.
} 
Diversi dalam Konvensi Hak-Hak Anak diatur dalam Pasal 40 ayat (3) huruf b. Walaupun tidak secara tegas menyatakan istilah diversi dalam ketentuan Pasal 40, namun Konvensi Hak-Hak Anak memberikan peluang bagi Negara peserta untuk menyelesaikan perkara anak yang terlibat dengan masalah hukum dapat dilakukan tanpa melibatkan proses peradilan. Instrument selanjutnya, yaitu The Riyadh Guidelines, dalam prinsip dasarnya mengingatkan bahwa anak yang melakukan tindak pidana ringan tidak harus direaksi dengan pengkriminalisasian atau penghukuman atas perbuatannya. Dengan demikian, instrument ini juga memberikan peluang untuk menyelesaikan masalah anak yang berkaitan dengan tindak pidana ringan untuk dapat diselesaikan tanpa pengkriminalisasian maupun penghukuman. Diversi hanya disinggung dalam Rule 58 The Riyadh Guidelines. Rule 58 The Riyadh Guidelines mengatur bahwa Penegakan hukum dan pihak yang terlibat di dalamnya harus terlatih untuk menangani anak. Dalam hal ini dimungkinkan untuk melakukan diversi pada perkara anak.

The Beijing Rules menegaskan dasar diversi dalam Rule 11 bagi aparat penegak hukum untuk melaksanakan diversi (pengalihan) di setiap tingkatan, baik pada tahap penyidikan, penuntutan maupun persidangan. Diversi diartikan sebagai alternatif penyelesaian perkara anak di luar proses peradilan yang formal.
United Nations Rules for The Protection of Juvenile Deprived of Their Liberty (UNRPJ) memberikan penjelasan pengaturan bahwa perampasan kemerdekaan merupakan upaya terakhir untuk jangka waktu yang paling pendek dan untuk kasus-kasus tertentu saja. Hal ini dapat dimaknai bahwa perlu ada alternatif lain dalam penyelesaian perkara anak di luar penjatuhan perampasan kemerdekaan. Walaupun Instrument ini tidak secara eksplisit menegaskan tentang diversi, namun isi dari instrument ini dapat digunakan sebagai dasar penyelenggaraan diversi.

Selanjutnya, Tokyo Rules dalam Rule 5 memberikan peluang dilakukannya diversi pada tahap pre trial. Hal ini dimaksudkan untuk melindungi kepentingan masyarakat, pencegahan kejahatan,atau untuk menghargai hukum dan hak-hak korban. Pencatuman diversi dalam beberapa instrument internasional anak merupakan suatu bentuk perhatian negara-negara di dunia dalam memberikan perlidungan terhadap anak nakal. Perkara anak nakal diupayakan untuk diselesaikan melalui proses non formal (pengadilan) dengan memperhatikan dampak buruk atau negatif dari penyelenggaraan proses formal (pengadilan) bagi anak, berupa stigma yang melekat maupun terjadinya pengulangan tindak pidana oleh anak.

Hal-hal terkait dengan diversi secara keseluruhan dapat diringkas dalam tabel berikut. 
Tabel 1

Instrument Internasional Anak yang Terkait dengan Diversi

\begin{tabular}{|c|c|c|c|}
\hline No. & Instrumen & Pasal & Isi \\
\hline 1. & $\begin{array}{l}\text { Konvensi Hak-Hak Anak } \\
\text { (Tidak mengatur diversi) }\end{array}$ & 40 ayat 3 huruf b & $\begin{array}{l}\text { Bila diperlukan dan dikehendaki tindakan } \\
\text { terhadap anak dapat diselesaikan tanpa } \\
\text { melibatkan proses peradilan (penyelesaian } \\
\text { perkara di luar jalur formal) }\end{array}$ \\
\hline 2. & $\begin{array}{l}\text { The Riyadh Guidelines } \\
\text { (mengatur Diversi dalam } \\
\text { Pasal 58) }\end{array}$ & $\begin{array}{l}46 \\
56\end{array}$ & $\begin{array}{l}\text { Program pelayanan masyarakat harus } \\
\text { dikembangkan sebagai upaya pencegahan } \\
\text { kejahatan. Penyelesaian secara formal } \\
\text { merupakan upaya terakhir. } \\
\text { Perampasan kemerdekaan merupakan upaya } \\
\text { terakhir dan untuk waktu yang singkat dengan } \\
\text { memperhatikan kepentingan terbaik bagi anak } \\
\text { dengan criteria tertentu sesuai dengan keadaan. } \\
\text { Untuk mencegah stigmatisasi, viktimisasi dan } \\
\text { kriminalisasi lebih lanjut perlu pelaksanaan } \\
\text { peraturan perundangan yang membatasi } \\
\text { penggunaan pemidanaan } \\
\text { Penegakan hukum dan pihak yang terlibat di } \\
\text { dalamnya harus terlatih untuk menangani anak. } \\
\text { Dalam hal ini dimungkinkan untuk melakukan } \\
\text { diversi } \\
\text { pada perkara anak. }\end{array}$ \\
\hline 3. & $\begin{array}{l}\text { The Beijing Rules } \\
\text { (mengatur Diversi dalam } \\
\text { Rule 11) }\end{array}$ & 11 & $\begin{array}{l}\text { Aparat penegak hukum dapat melakukan } \\
\text { diskresi pada setiap tingkatan pemeriksaan } \\
\text { perkara anak. } \\
\text { Diversi merupakan upaya pengalihan } \\
\text { penyelesaian perkara anak di luar proses } \\
\text { peradilan formal dengan tujuan menghindarkan } \\
\text { stigmatisasi anak. } \\
\text { Penahanan merupakan upaya terakhir dalam } \\
\text { dalam waktu yang singkat, dipisahkan dari orang } \\
\text { dewasa. }\end{array}$ \\
\hline 4. & $\begin{array}{l}\text { UNRPJ } \\
\text { (tidak mengatur tentang } \\
\text { diversi) }\end{array}$ & Bagian I & $\begin{array}{l}\text { Perampasan kemerdekaan merupakan upaya } \\
\text { terakhir,untuk jangka waktu yang paling pendek } \\
\text { dan untuk kasus-kasus tertentu saja. Pihak- } \\
\text { pihak yang berwenang memiliki kewajiban } \\
\text { meningkatkan perhatian kesadaran masyarakat } \\
\text { terhadap anak dan mempersiapkan anak kembali } \\
\text { ke lingkungan masyarakat sebagai bentuk } \\
\text { pelayanan sosial. Untuk itu diperlukan langkah- } \\
\text { langkah untuk membuka hubungan antara anak } \\
\text { dengan masyarakat sekitar. }\end{array}$ \\
\hline
\end{tabular}




\begin{tabular}{|c|c|c|c|}
\hline 5, & $\begin{array}{l}\text { Tokyo Rules } \\
\text { (Rule } 5 \text { mengatur tentang } \\
\text { diversi } \\
\text { pada tahap pre-trial) }\end{array}$ & 6 & 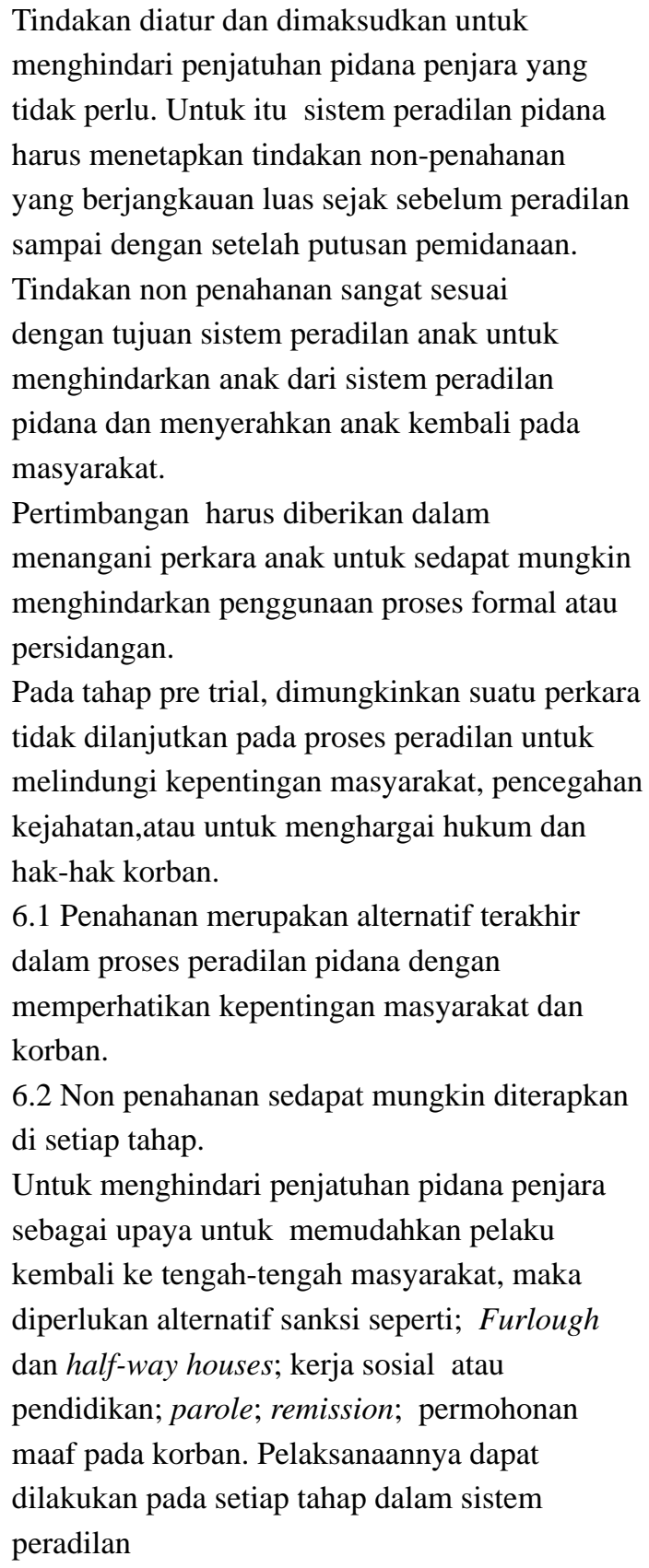 \\
\hline
\end{tabular}

(Sumber: bahan hukum primer (Konvensi Hak-Hak Anak, The Riyadh Guidelines, The Beijing Rules, UNRPJ, Tokyo Rules), diolah) 
Pencatuman diversi dalam beberapa instrument internasional anak merupakan suatu bentuk perhatian negara-negara di dunia dalam memberikan perlidungan terhadap anak nakal. Perkara anak nakal diupayakan untuk diselesaikan melalui proses non formal (pengadilan) dengan memperhatikan dampak buruk atau negatif dari penyelenggaraan proses formal (pengadilan) bagi anak, berupa stigma yang melekat maupun terjadinya pengulangan tindak pidana oleh anak.

Implikasi Yuridis dari Pengaturan Diversi dalam Instrumen Internasional Anak bagi Perlindungan Hukum Terhadap Anak Nakal di Indonesia

Bila ditelaah, uraian pasal demi pasal dalam UU Pengadilan Anak menunjukkan penyelesaian secara formal. Dimulai dari tahap penyidikan, penyidik anak telah diberi kewenangan untuk melakukan penahanan. Dilanjutkan proses penuntutan oleh penuntut anak, proses persidangan di Pengadilan hingga pelaksanaan putusan pengadilan terkait dengan perkara anak nakal. UU Pengadilan Anak menonjolkan pendekatan yuridis formal dalam penyelesaian perkara anak dan tidak mengatur tentang diversi. ${ }^{13}$ Tanpa disadari membawa dampak negatif berupa stigmatisasi. Secara psikologis, kondisi itu dapat mengganggu anak karena mereka pun tertekan karena stigma yang diberikan oleh masyarakat. ${ }^{14}$

Pemberian stigma pada diri anak menjadi pendorong bagi anak untuk mengulangi lagi perbuatannya di masa mendatang. ${ }^{15}$ Label tersebut diyakini berpengaruh pada tingkah laku anak pada masa yang akan datang karena dalam prakteknya justru memunculkan kenakalan baru. Label bagi anak muncul sejak tahap awal dari sistem peradilan pidana anak, walaupun secara nyata Mardjono mengatakan bahwa tahap persidangan merupakan tahap yang harus dianggap dominan dalam seluruh proses. ${ }^{16}$ Pada tahap persidangan, proses stigmatisasi mencapai puncaknya. ${ }^{17}$

UU Pengadilan Anak belum secara komprehensif memberikan perlindungan kepada anak nakal, sehingga tidak sesuai lagi dengan perkembangan dan kebutuhan hukum masyarakat.
Pemerintah menganggap perlu untuk mengganti UU Pengadilan Anak yang berlaku saat ini dengan undang-undang baru. RUU Sistem Peradilan Pidana Anak yang saat ini sedang disusun dan direncanakan akan menggantikan posisi UU Pengadilan Anak.

RUU Sistem Peradilan Pidana 2009 Anak dalam Pasal 1 ayat (2) memberikan arti tentang diversi. Menurut pasal tersebut, diversi adalah suatu pengalihan penyelesaian kasus anak yang diduga melakukan tindak pidana tertentu, dari proses pidana formal ke penyelesaian damai antara tersangka/terdakwa/pelaku tindak pidana dengan korban yang difasilitasi oleh keluarga dan/ atau masyarakat, Pembimbing Kemasyarakatan Anak, dan/atau penegak hukum yang bertanggung jawab sesuai dengan tingkat pemeriksaan.

Pengaturan yang demikian dimaksudkan untuk memberikan kepastian hukum dan supaya tidak menimbulkan multitafsir diantara para penegak hukum dalam melaksanakan diversi. Pengertian diversi yang dituangkan dalam Pasal 1 ayat (2) RUU Sistem Peradilan Pidana Anak sejalan Rule 11.2 The Beijing Rules maupun pendapat para sarjana.

Lebih lanjut RUU Sistem Peradilan Pidana Anak mengatur kriteria perkara yang dapat didiversi, dasar pertimbangan dilakukanya diversi, pelaksanaannya dapat dialkukan pada tiap-tiap tingkatan pemerikasaan dan pengawasan terhadap anak yang didiversi. Hal tersebut tertuang dalam Pasal 11 sampai dengan Pasal 15 RUU Sistem Peradilan Pidana Anak,

Pengaturan diversi secara khusus nantinya dalam UU Sistem Peradilan Pidana Anak di Indonesia diharapkan mampu menjadi pedoman bagi aparat penegak hukum dalam melaksanakan diversi untuk meminimalisasi keterlibatan anak dalam sistem peradilan serta menghindarkan anak dari stigmatisasi. Pengaturan tersebut perlu memperhatikan ketentuan internasional anak.

Kepolisian Republik Indonesia sebenarnya telah membekali penyidik anak dengan Telegram Rahasia Kabareskrim Polri Nomor: TR/1124/ IX/2006. Telegram Rahasia (TR) tersebut berisi

13 http://www.legalitas.org/content/peradilan-restoratif-suatu-pemikiran-alternatif-sistem-peradilan-anak-indonesia diakses tangal 13 April 2010.

14 http://64.203.71.11/kompas-cetak/0404/21/Jabar/983566.htm diakses tanggal 18 Juni 2008.

15 Paulus Hadisuprapto, Op.cit., h. 212.

16 Romli Atmasasmita, Sistem Peradilan Pidana, Bina Cipta, Bandung, 1996, h. 42.

17 Ibid., h. 43. 
tentang pedoman penyelenggaraan diversi dalam perkara anak. Salah satu alasan dikeluarkannya TR tersebut adalah masih adanya kecenderungan penyelesaian perkara anak dengan menggunakan proses formal dan masih sangat miskinnya kreativitas dalam mencari alternatif penyelesaian perkara anak di luar jalur formal. ${ }^{18}$

Penyelesaian perkara anak dalam TR Kabareskrim Polri tersebut menghimbau agar jajaran Polri memperhatikan beberapa hal berikut ini.

Mengedepankan asas kepentingan terbaik bagi anak sebagai landasan utama dalam mengambil keputusan tentang pola penanganan terhadap perkara anak.

Berusaha mencari alternatif penyelesaian terbaik bagi kepentingan tumbuh kembang anak dan sedapat mungkin berupaya menjauhkan anak dari proses peradilan formal/pengadilan.

Menghentikan praktek mencukur rambut anak, mengambil uang/barang milik anak yang tidak berhubungan dengan perkara anak, menyuruh anak membersihkan kantor polisi/ mencuci mobil, memberi hukuman fisik, menelanjangi, menganiaya, membentak dan menempatkan anak dalam satu ruangan dengan tahanan dewasa, mempublikasikan anak pada media.

Mengembangkan kemitraan dengan berbagai pihak yang peduli terhadap persoalan anak untuk mendapatkan masukan sebagai bahan kajian dalam mencari alternatif lain dalam penyelesaian perkara anak. ${ }^{19}$

Berdasarkan uraian di atas, walaupun penyidik anak telah dibekali dengan TR Kabareskrim Polri Nomor : TR/1124/XI/2006, namun tidak dapat dilaksanakan secara maksimal. Hal ini disebabkan karena TR tidak termasuk dalam bentuk peraturan perundang-undangan. Berdasarkan Pasal 7 (1) Undang-Undang Nomor 10 Tahun 2004 tentang Pembentukan Peraturan Perundang-Undangan, hirarki peraturan perundang-undangan adalah :

Undang-Undang Dasar Negara Republik Indonesia Tahun 1945;

Undang-Undang/Peraturan Pemerintah Pengganti Undang-Undang (Perpu);

Peraturan Pemerintah;

Peraturan Presiden;

Peraturan Daerah.
Melalui upaya harmonisasi hukum, BPHN merekomendasikan, pertama, mengintroduksir hak-hak anak dalam Konvensi Hak-Hak Anak ke dalam perundang-undangan hukum nasional, kedua, peninjauan kembali hukum positif yang tidak sesuai dengan Konvensi Hak-Hak Anak, dan ketiga, melakukan identifikasi kemungkinan perlunya penyusunan peraturan-perundang-undangan. Konsekuensinya menurut Erma Syafwan Syukrie, pemerintah Indonesia harus melakukan langkah-langkah harmonisasi hukum, yaitu: (1) memeriksa dan menganalisis perundang-undang yang ada dan masih sedang dalam perencanaan/pembentukan; (2) meninjau ulang lembaga-lembaga yang berhubungan dengan pelaksanaan hak anak; (3) mengusulkan langkahlangkah penyelerasan ketentuan Konvensi Hak-Hak Anak dengan perundang-undangan lain; (4) meninjau ulang bagian perundang-undangan yang masih berlaku, tetapi perlu penyempurnaan atau pelaksanaan yang tepat; (5) memprioritaskan acara pembuatan undang-undang yang diperlukan untuk mengefektifkan pelaksanan Konvensi Hak-Hak Anak atau penyelerasaan dengan perundang-undangan Indonesia. ${ }^{20}$

Pelaksanaan diversi di Indonesia dilakukan pada tingkat awal dalam sistem peradilan pidana, yaitu pada tahap pre judicial atau penyidikan. Hal ini mengigat polisi adalah aparat yang melaksanakan kontak awal dengan anak untuk mencegah terjadinya stigmatisasi sejak dini dan menghindarkan anak dari trauma yang terjadi bila proses peradilan anak berlangsung. Penyelesaian di luar jalur formal sesuai dengan Pasal 40 ayat 3 huruf b Konvensi Hak-Hak Anak dan Pasal 5 Tokyo Rules. Sedangkan pengaturan penanganan oleh polisi pada tingkat awal sesuai dengan Penjelasan Rule 12 The Beijing Rules.

Walaupun berdasarkan The Beijing Rules diversi dapat dilaksanakan disemua tingkatan, seyogyanya diversi di Indonesia dilaksanakan pada tingkat penyidikan di kepolisian. Seiring dengan hal tersebut, Pasal ayat (1) 18 UU No. 2 Tahun 2002 tentang Kepolisian Republik Indonesia menyebutkan bahwa, untuk kepentingan umum pejabat Kepolisian Negara Republik Indonesia dalam melaksanakan tugas dan 
wewenangnya dapat bertindak menurut penilaiannya sendiri. Pada ayat (2), Pelaksanaan ketentuan sebagaimana dimaksud dalam ayat (1) hanya dapat dilakukan dalam keadaan yang sangat perlu dengan memperhatikan peraturan perundangundangan, serta Kode Etik Profesi Kepolisian Negara Republik Indonesia. Hal tersebut terkait erat dengan diskresi.

Diversi berbeda dengan diskresi, namun memiliki kaitan erat. Diskresi oleh kepolisian adalah suatu tindakan kepolisian berdasarkan atas penilaian sendiri seorang petugas polisi dalam rangka kepentingan umum. Dalam pelaksanaannya, tindakan diskresi tetap harus memperhatikan rambu-rambu aturan yang berlaku dan dapat dipertanggungjawabkan secara moral, tidak dimuati interes pribadi, serta harus terukur atau seimbang antara tindakan polisi dengan berat ringannya kesalahan serta tepat situasi. Diskresi merupakan "baju kepolisian" dalam menjalankan tugasnya. Diskresi dilakukan oleh petugas polisi di lapangan adalah untuk menyelaraskan situasi, dengan keharusan seorang polisi untuk bersikap tepat dan cerdas dalam perannya, tidak hanya sebagai penegak hukum, tapi sekaligus sebagai pelindung, pengayom dan pelayan masyarakat. ${ }^{21}$

Sebagaimana diamanatkan dalam Rule 6 The Beijing Rules, bahwa diskresi dapat dilakukan disemua tingkatan dalam sistem peradilan pidana, baik pada tingkat penyidikan, penuntutan maupun persidangan. Diskresi merupakan bagian dari diversi.

Seperti telah diuraikan sebelumnya bahwa dalam proses peradilan anak, pertama-tama anak dihadapkan kepada aparat kepolisian. Kontak awal dengan penegak hukum ini sangat mempengaruhi tingkah laku selanjutnya dari tersangka anak. Pengalaman seorang tersangka dalam suatu proses tertentu mempengaruhi sikapnya terhadap proses berikutnya. Hal tersebut untuk menghindari rasa kecewa dan putus asa yang dapat mempengaruhi sikap anak selanjutnya. Hal ini sejalan dengan Rule 10.3. The Beijing Rules: kontak dengan badan penegak hukum dan anak-anak yang melanggar hukum harus diatur sedemikian rupa untuk menghormati status hukum dari anak tersebut, mempromosikan kelakuan baik dari si anak dan meng- hindari kesalahan yang membahayakan mereka, dengan memperhatikan keadaan kasusnya.

Aparat kepolisisan merupakan ujung tombak dalam pelaksaan peradilan anak. Berdasar pada Pasal 16 (3) UU No. 23 tahun 2002 juga menegaskan bahwa penangkapan, penahanan atau tindak pidana penjara anak hanya dilakukan apabila sesuai dengan hukum yang berlaku dan hanya dapat dilakukan sebagai upaya terakhir. Walaupun tidak ditegaskan mengenai diversi, namun atas dasar ketentuan Pasal 16 (3) UU Pengadilan Anak, penyidik anak, jaksa anak dan hakim anak dapat mempertimbangkan pelaksanaan diversi dalam perkara anak,

Penyidik Anak harus memperhatikan Anak Nakal secara khusus. Pengertian khusus tersebut adalah menangani Anak Nakal secara simpatik, efektif, afektif dan melindungi serta mengayomi anak agar dapat menyongsong masa depannya yang lebih panjang itu lebih baik. Hal ini didasarkan pada fakta psikologis bahwa sifat emosional anak masih labil, sehingga diharapkan dengan pendidikan khusus Anak Nakal tidak mengalami frustasi yang berlebihan.

Melalui proses penyidikan ini, Penyidik Anak diharapkan mampu mengungkap berbagai informasi dari tersangka anak tanpa melukai fisik dan psikis dari tersangka anak tersebut dengan melakukan pendekatan secara efektif, afektif dan simpatik. Penyidik Anak harus berpengetahuan luas dan mendalam agar Berita Acara Pemeriksaan (BAP) dapat dibuat secara obyektif dan terhindar dari sewenang-wenang.

Penyidik anak perlu dibekali dengan pelatihan dan pendidikan khusus. Sebagaimana diatur dalam Rule 12.1 The Beijing Rules. Pemberian pendidikan dan pelatihan khusus bagi aparat kepolisian yang berhubungan dengan anak ternyata berlaku juga di Jepang. Hal ini seperti yang diungkapkan oleh Shikita dan Tsichiya, bahwa: "Police work with juveniles is considered a specialized field and police officers working with juveniles are given special training" 22 . Penjelasan Rule 12 The Beijing Rules mengungkapkan, bahwa Rule 12 The Beijing Rules menggambarkan perhatian mengenai dibutuhkannya pelatihan-pelatihan khusus bagi semua penegak hukum yang terlibat

21 Elfiana, Malakah Penyelesaian Kasus Anak Melalui Diversi Dan Restorative Justice, 2009, Poltabes Banda Aceh, Tanggal 31 Maret 2009

22 Shikita and Tsichiya, UNDSRI (United Nations Social Defence Research Institute), 1976, Februari, Juvenile Justice an International Survey, Country Reports, Related Materials and Suggestions for future Research, Publication No.12, Rome, h. 60 
dalam proses peradilan anak. Hal ini disebabkan karena polisi merupakan kontak awal dari sistem peradilan anak, maka sangat penting bagi mereka untuk bertindak sesuai dengan cara yang tepat sebagai tindakan pencegahan kontrol terhadap kejahatan anak dan penanganan pelanggaran yang dilakukan oleh anak.

Lebih lanjut Rule 22.1 The Beijing Rules menegaskan, bahwa pendidikan profesional dan model lain yang tepat yang diistruksikan harus bermanfaat bagi perawatan profesional dari semua orang yang terlibat dalam perkara tindak pidana anak. Kemudian dalam Rule 22.2 The Beijing Rules menekankan, bahwa personil yang terlibat dalam peradilan anak harus memperhatikan berbagai perbedaan antara setiap anak, yang akan berhubungan dengan sistem peradilan anak. Usaha-usaha yang dilakukan harus mencerminkan perwakilan yang adil dari golongan wanita dan minoritas dalam peradilan anak.

Penjelasan Rule 22 The Beijing Rules menekankan, bahwa kekuasaan peradilan anak harus terdiri dari orang-orang dengan latar belakang yang berbeda (dalam berbagai sistem peradilan). Untuk itu dibutuhkan keahlian di bidang hukum, psikologi, kriminologi dan pengetahuan tentang perilaku. Kualifikasi profesional merupakan elemen penting dalam meyakinkan peradilan yang efektif dan tidak bersifat parsial. Lebih jauh diupayakan untuk meyakinkan kemungkinan dipilihnya petugas wanita dalam peradilan anak, dan kriteria yang digunakan akan diambil dari rekruitment, pelatihan, dan memfasilitasi wanita dalam peradilan anak.
Diversi menjadi pertimbangan penting untuk dapat diterapkan pada perkara-perkara anak, mengingat bahwa anak merupakan pribadi yang belum matang baik secara fisik maupun psikis sehingga belum dapat memahami hal-hal yang benar maupun yang salah. Kenakalan yang dilakukan oleh anak tidak harus diselesaikan melalui jalur formal, untuk menghindarkan anak dari proses hukum yang dapat berdampak stigmatisasi dan pengulangan bagi mereka. Keadaan demikian dapat menghancurkan masa depan anak. Penyelesaian melalui jalur non formal menjadi alternatif karena penghukuman bagi anak dipilih sebagai jalan terakhir dan semata-mata untuk kepentingan terbaik bagi anak.

\section{Kesimpulan}

Peraturan internasional anak yang mengatur tentang diversi hanya Rule 11 The Beijing Rules, Rule 58 The Riyadh Guideline serta Rule 5 Tokyo Rules. Sementara intrument internasional lainnya seperti Konvensi Hak-Hak Anak dan UNRPJ hanya memberikan pengaturan mengenai pertimbangan untuk sedapat mungkin melakukan penyelesaian perkara anak di luar jalur formal (persidangan) dan sedapat mungkin menghindarkan penahanan dan penjatuhan sanksi pidana bagi anak dengan menyediakan alternatif-alternatif saksi lain yang lebih tepat bagi anak.

Pengalihan penyelesaian perkara anak ke luar jalur formal peradilan melalui diversi yang diatur dalam instrument internasional anak membawa implikasi yudidis bagi Indonesia untuk mengakomodir ketentuan diversi dalam peraturan perundang-undangan anak di Indonesia.

\section{DAFTAR PUSTAKA}

Astuti, Made Sadhi, Dkk, 2007, Perlindungan Hukum Bagi Anak Nakal Pada Proses Persidangan (Studi Di Pengadilan Negeri Malang Dan Pengadilan Negeri Surabaya), Hasil Penelitian Dasar, Universitas Brawijaya Malang.

Atmasasmita, Romli, 1996, Sistem Peradilan Pidana. Bina Cipta, Bandung

Dellyana, S., 1998, Wanita Dan Anak Di Mata Hukum, Yogyakarta, Liberty.
Elfiana, 2009, Malakah Penyelesaian Kasus Anak Melalui Diversi Dan Restorative Justice, 2009, Poltabes Banda Aceh, Tanggal 31 Maret 2009

Hadisuprapto, Paulus, 2008, Delinkuensi Anak Pemahaman dan Penanggulangannya, Malang, Bayumedia.

Marlina, 2007, Diversi dan Restorative Justice sebagai Alternatif Perlindungan terhadap Anak yang Berhadapan dengan Hukum, 
Pusat Kajian dan Perlindungan anak (PKPA), Medan.

Rover. C. De, 2000, To Serve and To Protect Acuan Universal Penegakan HAM. Raja Grafindo Persada, Jakarta.

Shikita and Tsichiya, UNDSRI (United Nations Social Defence Research Institute), 1976, Februari, Juvenile Justice an International Survey, Country Reports, Related Materials and Suggestions for future Research, Publication No.12, Rome,

Siegel, Larry J., 2002, Juvenile Delinquency, Wadswort, United State of America.

Soemitro, Irma Setyowati. 1990, Aspek Hukum

Perlindungan Anak., Jakarta, Bina Aksara.

\section{Peraturan Perundang-Undangan}

Telegram Rahasia Kabareskrim Polri Nomor : TR/1124/XI/2006.

Undang-Undang Nomor 8 Tahun 1981 tentang Kitab Undang-Undang Hukum Acara Pidana.

Undang-Undang Nomor 3 Tahun 1997 tentang Pengadilan Anak.

Undang-undang Nomor 23 tahun 2002 tentang Perlindungan Anak.
Undang-Undang Nomor 10 Tahun 2004 tentang Pembentukan Peraturan PerundangUndangan

United Nations Convention on the Rights of the Child

United Nations Guidelines for the Prevention of Juvenile Delinquency (The Riyadh Guidelines)

United Nation Standard Minimum Rules for the Administration of Juvenile Justice (The Beijing Rules)

United Nations Rules for The Protection of Juvenile Deprived of Their Liberty (UNRPJ)

United Nations Standard Minimum Rules for Non-custodial Measures (Tokyo Rules)

Internet

http://64.203.71.11/kompas-cetak/0404/21/ Jabar/983566.htm

http://m.hukumonline.com/berita/baca/ It4d669dccee142/ batas-usia-anak-dapatdipidana-naik

http://www.legalitas.org/content/peradilanrestoratif-suatu-pemikiran-alternatifsistem-peradilan-anak-indonesia 